\title{
Evaluation of Nigerian Teachers Performance by Some Selected Parents in Oke-Ogun Local Government Education Areas of Oyo State, Nigeria
}

\author{
Fehıntola, J. Olusola \\ Dept. of Guidance \& Counselling, University of Ibadan, Ibadan \\ Email: jof677@yahoo.com
}

\section{Doi:10.5901/jesr.2015.v5n2p177}

\begin{abstract}
From time immemorial, teaching has remained a complex process. This complexity stems from the general belief that anybody can teach. Beginning from the housewife who taught her daughter how to prepare food to a roadside mechanic who taught his apprentice how to service a car, it is the act of teaching that has taken place. The above impression of teaching also affects the societal perception of a teacher. Many people see nothing special in what a teacher does. Therefore, this paper is specifically focused on the perception of parents about how they perceive teachers and their duties in the ten Local Government Education Areas (LGEA) of Oke-ogun, Oyo state. A sample of 673 participants was taken for the study. This comprises of 391 men and 282 women with average age of 51.25years and standard deviation of 2.36years. Descriptive research design was used for the study and simple random sampling was used for the study. The study was carried out to identify the roles of the teachers as role models to the learners in the academic performance of learners in public examinations and in the mode of behaviour as means of providing solution to the problem. The manners in which they perform their duty are actually working against effective performance of our learners in schools and in their ways of life. The researcher recommends that the government should try as much as possible to inaugurate a very formidable monitoring group that will check the excesses of these teachers to forestall wastages in the educational sector. It is of the opinion of the researcher that if the abovementioned factors are put into consideration in teaching-learning process, there may be improvement in the performances and the behaviour of learners in our schools and society at large.
\end{abstract}

\section{Introduction}

From time immemorial, teaching has remained a complex process. This complexity stems from the general belief that anybody can teach. Beginning from the housewife who taught her daughter how to prepare food to a roadside mechanic who taught his apprentice how to service a car, it is the act of teaching that has taken place. The above impression of teaching also affects the societal perception of a teacher. Many people see nothing special in what a teacher does .To this category of people, teaching is what everybody does and as such nothing special in being a teacher. This wrong notion of teaching can also be attributed to some concepts that share the same boundary with teaching yet, they are completely different. Such concepts are: Instructing and Indoctrinating.

Most psychologists have given some definitions of teaching. Teaching has been seen as the act of imparting knowledge. Others perceive teaching as the process of passing esoteric knowledge to learners. However, Adufe (2005) defined teaching as a deliberate, conscious and concise attempt to communicate the content of an instruction to students by the teacher who is experienced, matured and trained to do so. By this definition of teaching, it has always been seen as a conscious and deliberate effort. No teacher can say he is teaching a particular concept by accident. The time spent in preparation before going to classroom to deliver the lesson or teach negates that.

The knowledge disseminated by the teacher is not a knowledge that can be easily gotten. It requires going for necessary training in institutions formally recognized and reputable for passing such knowledge. This knowledge is acquired after a number of years and success in pre-selected examinations would have been met. Teaching involves three actors: the teacher, the students and the content to be learnt. The three are so indispensable that teaching process is completely threatened in the absence of any of these necessary components. Teaching involves complex documentation of procedures and processes. This indeed separates teaching from other methods of disseminating knowledge.

These complex procedures clearly specify what the teacher as well as the student should engage in at specific steps, time and levels. If these steps justify the sequential nature of teaching, in the act of teaching, the approach cannot be anyhow. Teaching is a process of effective communication. The success or otherwise of teaching is a function of how 
perfect the outlets are. The whole process is organic in nature. Teaching operates like a system. Any dysfunction experienced by any components of the system causes a major breakdown of the whole system and process. Where teaching process experiences hiccups, a lot of questions agitate the mind of a teacher.

The above also receive the attention of an ordinary communication that does not succeed from the above, or the purpose of effective teaching, the various channels of disseminating teaching must be put a right. Teaching is also a process of decision-making. Far-reaching and consequential decisions are taken by the teacher before and after teaching. He decides on what to teach, whom to teach, how to teach, why the topic is being taught and above all, how to measure the outcome of teaching in order to conclude whether the effort has succeeded or not.

Instructing is a form of passing information. The usual classroom dialogue existing between a teacher and his students may not necessarily be so worth instructing. An instructor may know how to instruct his students to carry out laid down activities. He does not need to justify the reason for engaging his students in such activities as is the case with teachers. The process of instructing gives respect to the authority of the instructor as a knowledge magician. Students learn through the act of imitation. The success is determined by students' abilities to repeat what the teacher has taught. No room is created for extrapolation and as such it does not appeal to the sense of innovation and independence of the learners.

The twin brother of instructing or indoctrinating is a method of passing information with little or no resistance from the recipients. Total conformity to the prescribed knowledge on the part of the learners is the hallmark of indoctrinating. While indoctrinating as a method can assist in the teaching of certain subjects that preach morality and adherence to creeds, it may be intellectually preconscious. Indoctrinating is averse to creativity and innovation and as such; it will not welcome any teaching used this time around. The beauty of indoctrination will reflect in the following activities viz: warning, flying or saluting the national flag of a country, singing the national anthem, recitation of national pledge, giving or receiving National Awards, singing of religious hymns and choruses.

Based on the importance of teacher in the teaching-learning process this study is set out to examine how the public perceived the teachers in the course of teaching-learning process and as the custodians of knowledge from where our children are to learning and become dependent in the future as role model in terms of moral, knowledge and dependability. This study intend to find out the impact of the teachers in the life of the learners both academically and moral wise, since the number of hours the learners are staying in school is more than the one they spend at home one would think that if the teachers are academically sound and morally upright the learners should imitated them in all areas of life like hard work, decent dressing, righteousness and total uprightness which are qualities that teachers are known with.

\subsection{Statement of the problem}

In Nigeria of today the learners from different educational levels are not different from the drop out and those that has never been to the four walls of the classroom in terms of moral decadency, laziness, indecent dressing and at large inability to display academic competence in terms of reasoning and in articulation in the real life situation. Due to these factors the parents are unhappy and they could not see the reason for sending their child or ward to school. It is not uncommon to hear the parents saying at least if the children are not academically sound they should be morally sound, most especially with the introduction of civic education in to the school curricular. The unhappiness of the parents gained more ground whenever any public examination results are released eg West African Senior School Certificate Examination results and National Examination Council Results. Student's outcomes do not match the government and parental investment expectation. All stakeholders are concerned about why the system is turning out graduates with poor results. To them, it is questionable whether or not teachers in the various educational categories are not doing what is expected of them or whether they are not competent or what? Also, from time to time we heard and read some shameful acts perpetrated by our learners as if they do not have any good role model that they can imitate among their teachers. Atimes one would begin to wonder whether the teachers are the one that are motivating them to do, for gone are the days when learners fear the teachers more than their parents and they would not want to do anything that will make them to lose face in the presence of their teachers. From these aforementioned points this study stands to examine the perception of parents on qualities of our teachers in terms of academic competence and moral standard.

\subsection{Purpose of the Study}

The purpose of this study is to examine, what the teachers' characteristics are as perceived by the parents and to know 
whether there is going to be any significant difference between the perception of (male and female) parents on the qualities of teachers in the selected schools in Oke-ogun LGA of Oyo State.

\subsection{Significance of the Study}

Findings of this study will provide educational planners and administrators with adequate information about teachers' qualities as it affects learning outcome and moral behaviour of the learners. This will also help the parents to know why the learners perform poorly and it will help to know what to do to resolve the problem of wastages on the parts of the parents and government at all levels. It will also help in the course of recruiting the teachers. On the parts of the learners, it will help them to receive quality, moral and sound teaching from their teachers and prepare them for future purposes, instead of wasting their time for fun and turn them to be half baked, and finally become miscreants. This study has to do with the perception of the parents on qualities of the teachers in Oke-ogun Local Government Areas of Oyo State.

\section{Methodology}

The research design used is descriptive research design of survey type. This type of research method was considered appropriate because of the nature of this study which has to do with the attitude of teachers to their duty and their life style. In this method, questionnaire was used as the research instrument to collect data from the Parents on their perception of the Nigerian teachers. The population comprises of parents resident in Oke-ogun area of Oyo state at large. The subjects for this study were selected parents from ten local government areas of Oyo state. The subjects were randomly selected in each of the local Governments using simple random sampling. A total number of six hundred and seventy three parents were used for the study to enable the researcher sample a wide range of opinions from parents on the qualities of Nigerian teachers as perceived by them. The researcher generated the research instrument based on the review of relevant literature in line with the objectives of the study. The instrument was a well structured Likert- type which consists of twenty-one (21) items assessing a wide range of views of Nigerians on qualities expected of teachers. The scale is in likert form as follows: $S A=1, A=2, D=3$ and $S D=4$. Respondents were asked to react to each of the items of the scale to indicate their perception of the situation of Nigerian teachers. The scale has the reliability coefficient of 0.74 using test-retest method. The administration of the instrument used was done in ten Local Government Areas of Oyo state. The researcher personally visited the parents selected for the study to administer the questionnaire. After the initial introduction, all the randomly selected parents were spoken to before the instrument was given to them and the researcher explained the purpose and procedure of responding to the questionnaire. At the long run 673 questionnaires were returned properly filled and the same was used for the study. The responses from respondents on the questionnaire used were scored section by section and the total scores for each of the last two sections were coded for computerized analysis. Inferential statistics of t-test and descriptive statistics of frequency counts and percentages were used for the analysis.

\section{Results}

\subsection{Research Question 1}

What teachers' characteristics are as perceived by the male and female parents which affect teachers' effectiveness in the selected Schools in Oyo State?

This research question was answered using frequency counts based on the data obtained as a result of using Teachers Assessment Rating Scale (TARS). 
Table 1: Analysis of Teachers' perception by Parents and TESCOM \& LGUBE officers

\begin{tabular}{|c|c|c|c|}
\hline Item & Agree & Disagree & Remarks \\
\hline Teachers use variety of methods when teaching. & $664(98.7 \%)$ & $9(6.4 \%)$ & $\begin{array}{l}\text { It is the true characteristics of } \\
\text { the Nigerian teachers. }\end{array}$ \\
\hline $\begin{array}{l}\text { Teachers are familiar with their students but cannot be a friend to all of } \\
\text { them. }\end{array}$ & $525(78.0 \%)$ & $148(22.0 \%)$ & $\begin{array}{l}\text { It is the true characteristics of } \\
\text { the Nigerian teachers. }\end{array}$ \\
\hline $\begin{array}{l}\text { Teachers have the right to compel their students to do things contrary } \\
\text { to their nature as long as it is beneficial to them. }\end{array}$ & $537(79.8 \%)$ & $136(20.3 \%)$ & $\begin{array}{l}\text { It is the true characteristics of } \\
\text { the Nigerian teachers. }\end{array}$ \\
\hline $\begin{array}{l}\text { Giving an individualized attention to each student will create } \\
\text { unnecessary familiarity. }\end{array}$ & $229(34.1 \%)$ & $444(65.9 \%)$ & $\begin{array}{l}\text { It is the true characteristics of } \\
\text { the Nigerian teachers. }\end{array}$ \\
\hline $\begin{array}{l}\text { Teachers love their students but whether they do well or not in their } \\
\text { studies is the sole responsibility and concern of their parents. }\end{array}$ & $237(35.2 \%)$ & $436(64.8 \%)$ & $\begin{array}{l}\text { It is the true characteristics of } \\
\text { the Nigerian teachers. }\end{array}$ \\
\hline Teachers tolerate and endure the dull students most of the time. & $172(25.4 \%)$ & $501(74.5 \%)$ & $\begin{array}{l}\text { It is the true characteristic of the } \\
\text { Nigerian teachers. }\end{array}$ \\
\hline $\begin{array}{l}\text { Teachers praise generously to create room for improvement among the } \\
\text { students in their class. }\end{array}$ & $614(91.3 \%)$ & $59(8.7 \%)$ & $\begin{array}{l}\text { It is the true characteristics of } \\
\text { the Nigerian teachers. }\end{array}$ \\
\hline $\begin{array}{l}\text { It is necessary for the teachers to move across the room toward the } \\
\text { student who is engaged in an unacceptable activity. }\end{array}$ & $70(10.4 \%)$ & $603(89.6 \%)$ & $\begin{array}{l}\text { It is the true characteristics of } \\
\text { the Nigerian teachers. }\end{array}$ \\
\hline $\begin{array}{l}\text { Teachers have the right to suspect something negative rather than } \\
\text { expect something positive from the students. }\end{array}$ & $435(64.7 \%)$ & $238(35.2 \%)$ & $\begin{array}{l}\text { It is the true characteristics of } \\
\text { the Nigerian teachers. }\end{array}$ \\
\hline $\begin{array}{l}\text { Teachers use any all means to let a student know that they care about } \\
\text { them. }\end{array}$ & $136(20.3 \%)$ & $537(79.8 \%)$ & $\begin{array}{l}\text { It is the true characteristics of } \\
\text { the Nigerian teachers. }\end{array}$ \\
\hline $\begin{array}{l}\text { It is only an incompetent teacher that will be willing to apologize to } \\
\text { his/her students when he or she is wrong. }\end{array}$ & $284(42.1 \%)$ & $389(57.8 \%)$ & $\begin{array}{l}\text { It is the true characteristics of } \\
\text { the Nigerian teachers. }\end{array}$ \\
\hline Teachers provide a helping hand at crucial time for the learners. & $513(76.3 \%)$ & $160(23.7 \%)$ & $\begin{array}{l}\text { It is the true characteristics of } \\
\text { the Nigerian teachers. }\end{array}$ \\
\hline $\begin{array}{l}\text { Teachers avoid penalizing the entire group for the offence of an } \\
\text { individual. }\end{array}$ & $222(33.0 \%)$ & $451(67.0 \%)$ & $\begin{array}{l}\text { It is the true characteristics of } \\
\text { the Nigerian teachers. }\end{array}$ \\
\hline $\begin{array}{l}\text { It is an act of show-off for a teacher to stand by the door after recess } \\
\text { just to indicate that a change of behaviour is necessary. }\end{array}$ & $397(59.0 \%)$ & $276(41.1 \%)$ & $\begin{array}{l}\text { It is the true characteristics of } \\
\text { the Nigerian teachers. }\end{array}$ \\
\hline $\begin{array}{l}\text { Materials to be used in any class need not necessarily be prepared } \\
\text { always. The teacher is an embodiment of knowledge. }\end{array}$ & $304(45.1 \%)$ & $369(54.9 \%)$ & $\begin{array}{l}\text { It is the true characteristics of } \\
\text { the Nigerian teachers. }\end{array}$ \\
\hline $\begin{array}{l}\text { Goals exist for each sequence of instruction. Therefore, both teachers } \\
\text { and learners must strive towards them. }\end{array}$ & $505(75.1 \%)$ & $168(24.9 \%)$ & $\begin{array}{l}\text { It is the true characteristics of } \\
\text { the Nigerian teachers. }\end{array}$ \\
\hline $\begin{array}{l}\text { It is not the responsibility of teachers to search for the underlying } \\
\text { causes of truancy, constant failure, slow reading and other } \\
\text { misbehaviour among the learners in the class. }\end{array}$ & $345(51.4 \%)$ & $327(48.6 \%)$ & $\begin{array}{l}\text { Not the true characteristics of } \\
\text { the Nigerian teachers }\end{array}$ \\
\hline $\begin{array}{l}\text { Teachers need to establish positive relationships with all classroom } \\
\text { participants. }\end{array}$ & 518(76.9\%) & $155(23.1 \%)$ & $\begin{array}{l}\text { It is the true characteristics of } \\
\text { the Nigerian teachers. }\end{array}$ \\
\hline $\begin{array}{l}\text { Teachers sometimes adopt systematic strategies involving social } \\
\text { rewards and tangible rewards when teaching. }\end{array}$ & 459(68.2\%) & $214(31.8 \%)$ & $\begin{array}{l}\text { It is the true characteristics of } \\
\text { the Nigerian teachers. }\end{array}$ \\
\hline $\begin{array}{l}\text { Teachers encourage the efforts of learners no matter how irritating or } \\
\text { unsatisfactory the learner behalf. }\end{array}$ & $257(37.5 \%)$ & $415(61.8 \%)$ & $\begin{array}{l}\text { It is the true characteristics of } \\
\text { the Nigerian teachers. }\end{array}$ \\
\hline
\end{tabular}

The results in table 1 show that the average Nigerian teacher portrays favourable characteristics toward the success of teaching-learning process in any classroom situation the low level performance of the students can be traced to another avenue connected to educational and academic performance of the learners.

\subsection{Research Question 2:}

Is there any significant difference in the responses of Parents assessment as it affects teachers' mode of operation in the selected schools in Oyo state? 
Table 2: Analysis of Teachers' perception by Parents and TESCOM \& LGUBE officers

\begin{tabular}{|c|c|c|c|c|c|c|}
\hline Item & Variables & $\mathbf{N}$ & Mean & S.D & $T$ & $\mathbf{P}$ \\
\hline Teachers use variety of methods when teaching. & $\begin{array}{c}\text { male } \\
\text { female }\end{array}$ & $\begin{array}{l}391 \\
282\end{array}$ & $\begin{array}{l}3.72 \\
3.47\end{array}$ & $\begin{array}{l}.570 \\
.704\end{array}$ & .009 & $>0.05$ \\
\hline $\begin{array}{l}\text { Teachers sometimes re-read the students materials several times } \\
\text { because things have changed from what they were } \\
\text { during their days. }\end{array}$ & $\begin{array}{l}\text { male } \\
\text { female }\end{array}$ & $\begin{array}{l}391 \\
282\end{array}$ & $\begin{array}{l}3.05 \\
2.88\end{array}$ & $\begin{array}{l}.415 \\
.592\end{array}$ & .055 & $>0.05$ \\
\hline $\begin{array}{l}\text { Teachers are familiar with their students but cannot be a friend to all of } \\
\text { them. }\end{array}$ & $\begin{array}{c}\text { male } \\
\text { female }\end{array}$ & $\begin{array}{l}391 \\
282\end{array}$ & $\begin{array}{l}3.19 \\
3.04\end{array}$ & $\begin{array}{l}.808 \\
.725\end{array}$ & 1.282 & $>0.05$ \\
\hline $\begin{array}{l}\text { Teachers have the right to compel their students to do things contrary } \\
\text { to their nature as long as it is beneficial to them. }\end{array}$ & $\begin{array}{c}\text { male } \\
\text { female }\end{array}$ & $\begin{array}{l}391 \\
282\end{array}$ & $\begin{array}{l}3.04 \\
3.01\end{array}$ & $\begin{array}{l}.717 \\
.814\end{array}$ & .260 & $>0.05$ \\
\hline $\begin{array}{l}\text { Giving an individualized attention to each student will create } \\
\text { unnecessary familiarity. }\end{array}$ & $\begin{array}{c}\text { Male } \\
\text { female }\end{array}$ & $\begin{array}{l}391 \\
282\end{array}$ & $\begin{array}{l}3.19 \\
2.48\end{array}$ & $\begin{array}{l}.755 \\
.921\end{array}$ & 5.634 & $<0.05$ \\
\hline $\begin{array}{l}\text { Teachers love their students but whether they do well or } \\
\text { not in their studies is the sole responsibility and concern } \\
\text { of their parents. }\end{array}$ & $\begin{array}{l}\text { male } \\
\text { female }\end{array}$ & $\begin{array}{l}391 \\
282\end{array}$ & $\begin{array}{l}2.89 \\
2.55\end{array}$ & $\begin{array}{l}.758 \\
.921\end{array}$ & 2.575 & $<0.05$ \\
\hline Teachers tolerate and endure the dull students most of the time. & $\begin{array}{c}\text { male } \\
\text { female }\end{array}$ & $\begin{array}{l}391 \\
282\end{array}$ & $\begin{array}{l}3.20 \\
2.64\end{array}$ & $\begin{array}{l}.673 \\
.832\end{array}$ & 4.955 & $<0.05$ \\
\hline $\begin{array}{l}\text { Teachers praise generously to create room for improvement } \\
\text { among the students in their class. }\end{array}$ & $\begin{array}{c}\text { male } \\
\text { female }\end{array}$ & $\begin{array}{l}391 \\
282\end{array}$ & $\begin{array}{l}3.63 \\
3.47\end{array}$ & $\begin{array}{l}.679 \\
.684\end{array}$ & 4.955 & $<0.05$ \\
\hline $\begin{array}{l}\text { It is necessary for the teachers to move across the room toward the } \\
\text { student who is engaged in an unacceptable activity. }\end{array}$ & $\begin{array}{c}\text { Male } \\
\text { female }\end{array}$ & $\begin{array}{l}391 \\
282\end{array}$ & $\begin{array}{l}2.92 \\
3.21\end{array}$ & $\begin{array}{l}.550 \\
.643 \\
\end{array}$ & -1.580 & $>0.05$ \\
\hline $\begin{array}{l}\text { Teachers have the right to suspect something negative rather than } \\
\text { expect something positive from the students. }\end{array}$ & $\begin{array}{c}\text { male } \\
\text { female }\end{array}$ & $\begin{array}{l}391 \\
282\end{array}$ & $\begin{array}{l}3.12 \\
2.64\end{array}$ & .790 & 4.660 & $<0.05$ \\
\hline $\begin{array}{l}\text { Teachers use any opportunity to let a student know that they care } \\
\text { about them. }\end{array}$ & $\begin{array}{c}\text { male } \\
\text { female }\end{array}$ & $\begin{array}{l}391 \\
282\end{array}$ & $\begin{array}{l}3.06 \\
3.05\end{array}$ & .671 & .094 & $>0.05$ \\
\hline $\begin{array}{l}\text { It is only an incompetent teacher that will be willing to apologize to } \\
\text { his/her students when he or she is wrong. }\end{array}$ & $\begin{array}{c}\text { Male } \\
\text { female }\end{array}$ & $\begin{array}{l}391 \\
282 \\
\end{array}$ & $\begin{array}{l}2.89 \\
2.53\end{array}$ & $\begin{array}{c}.823 \\
1.044 \\
\end{array}$ & 2.553 & $<0.05$ \\
\hline Teachers provide a helping hand at crucial time for the learners. & $\begin{array}{c}\text { male } \\
\text { female }\end{array}$ & $\begin{array}{l}391 \\
282\end{array}$ & $\begin{array}{l}3.06 \\
3.01\end{array}$ & $\begin{array}{l}.744 \\
.762\end{array}$ & .438 & $>0.05$ \\
\hline $\begin{array}{l}\text { Teachers avoid penalizing the entire group for the offence of an } \\
\text { individual. }\end{array}$ & $\begin{array}{l}\text { Male } \\
\text { Female }\end{array}$ & $\begin{array}{l}391 \\
282\end{array}$ & $\begin{array}{l}2.91 \\
2.89\end{array}$ & $\begin{array}{l}.813 \\
.831\end{array}$ & .160 & $>0.05$ \\
\hline $\begin{array}{l}\text { It is an act of show-off for a teacher to stand by the door after recess } \\
\text { just to indicate that a change of behaviour is necessary. }\end{array}$ & $\begin{array}{c}\text { male } \\
\text { female }\end{array}$ & $\begin{array}{l}391 \\
282\end{array}$ & $\begin{array}{l}2.96 \\
2.35\end{array}$ & $\begin{array}{l}.731 \\
.814\end{array}$ & 5.213 & $<0.05$ \\
\hline $\begin{array}{l}\text { Materials to be used in any class need not necessarily be prepared } \\
\text { always. The teacher } \\
\text { is an embodiment of knowledge. }\end{array}$ & $\begin{array}{l}\text { male } \\
\text { female }\end{array}$ & $\begin{array}{l}391 \\
282\end{array}$ & $\begin{array}{l}2.92 \\
2.17\end{array}$ & $\begin{array}{l}.769 \\
1.045\end{array}$ & 5.470 & $<0.05$ \\
\hline $\begin{array}{l}\text { Goals exist for each sequence of instruction. Therefore, both teachers } \\
\text { and learners must strive towards them. }\end{array}$ & $\begin{array}{l}\text { male } \\
\text { female }\end{array}$ & $\begin{array}{l}391 \\
282\end{array}$ & $\begin{array}{l}3.00 \\
3.11\end{array}$ & $\begin{array}{l}.786 \\
.953\end{array}$ & .839 & $>0.05$ \\
\hline $\begin{array}{l}\text { It is not the responsibility of teachers to search for the underlying } \\
\text { causes of truancy, constant failure, slow reading and other } \\
\text { misbehaviour among the learners in the class. }\end{array}$ & $\begin{array}{l}\text { male } \\
\text { female }\end{array}$ & $\begin{array}{l}391 \\
282\end{array}$ & $\begin{array}{l}2.82 \\
2.24\end{array}$ & $\begin{array}{l}.804 \\
1.113\end{array}$ & 4.027 & $<0.05$ \\
\hline $\begin{array}{l}\text { Teachers need to establish positive relationships with all classroom } \\
\text { participants. }\end{array}$ & $\begin{array}{c}\text { male } \\
\text { female }\end{array}$ & $\begin{array}{l}391 \\
282\end{array}$ & $\begin{array}{l}2.88 \\
3.23\end{array}$ & $\begin{array}{l}.736 \\
.938\end{array}$ & -2.777 & $<0.05$ \\
\hline $\begin{array}{l}\text { Teachers sometimes adopt systematic strategies involving social } \\
\text { rewards and tangible rewards when teaching. }\end{array}$ & $\begin{array}{c}\text { male } \\
\text { female }\end{array}$ & $\begin{array}{l}391 \\
282\end{array}$ & $\begin{array}{l}2.81 \\
3.07\end{array}$ & $\begin{array}{l}.808 \\
.827\end{array}$ & 23.630 & $<0.05$ \\
\hline $\begin{array}{l}\text { Teachers encourage the efforts of learners no matter how } \\
\text { unsatisfactory they are. }\end{array}$ & $\begin{array}{c}\text { male } \\
\text { female }\end{array}$ & $\begin{array}{l}391 \\
282\end{array}$ & $\begin{array}{l}2.64 \\
2.80\end{array}$ & $\begin{array}{l}.803 \\
.915\end{array}$ & 1.230 & $>0.05$ \\
\hline
\end{tabular}

The results from table 2 indicate that there is no significant difference in the perception of the male and female parents as regards the qualities and performance of Nigerian teachers.

\section{Discussion}

The resultant effect of the poor societal disposition to the teacher is evident in the number of good hands and brains that are walking away from the job especially at the basic and secondary education level. It thus becomes a difficult issue that 
need be addressed to ensure that the teachers take their rightful place among the league of professionals.

Attending to the yearnings and aspiration of the teachers become imperative for all concerned knowing fully well that the teachers' physical and psychological state and disposition are all crucial to teaching-learning processes. Some writers are of the opinion that the systematic impoverishment of teachers contribute to over $70 \%$ of the poor quality of education in Nigeria. The social stigma coupled with the various crucial outstanding challenges may not enhance the goal of teaching and ultimately the goal of education.

Teachers are very important in the school system. When you remove them, there will be a total collapse of the whole system. In fact the quality of an educational system is dependent on the quality of teachers in the system. This is why the National Policy on Education NPE (2007 revised) stresses the need to accord teacher education a prominent place in educational planning. Teachers are the professionals directly involved in the task of promoting teaching and learning. However, a situation where the category of teachers who form the core of classroom teaching whose major task revolves round the daily, face-to-face contact with pupils in the classrooms, laboratories and practical settings, are practically excluded from the curriculum and not fully involved or represented in the various educational projects calls for serious concern and re-examination. A situation whereby practicing teachers are only brought into the process through workshops while the whole conceptualization, planning and development of the programme is carried out only by the experts, researchers, educators and scholars in tertiary institutions cannot bring about the desirable result. This will only result in teacher participation and not involvement which cannot bring about a sense of responsibility, acceptance of ownership and strong commitment to the programme. The view upheld here is that involvement right from the conceptualization stage of any programme rather than the mere participation should be encouraged for successful implementation of our educational programmes.

Education stakeholder should therefore introduce professional development system assessment that will truly enhance teachers' professional growth and integration of activities that will have a positive impact on classroom instruction. This will to a large extent control the "fly-in-fly-out" syndrome of some of our in-service sessions which has not really proved to be effective in changing the way some teachers teach or impact knowledge.

Also, increased collaboration, authentic and classroom researches conducted by teachers with the result being used to make appropriate changes in content, teaching methods and assessment should be emphasized and encouraged by the education stakeholders. All these will go a long way to ensure effective continuing professional development, which ultimately can play positive roles in authentic school reform thus ensuring that young children of today are the generations to come have well secured future. Finally, there is no doubt that the teaching profession has become one of the steady and most reliable of all careers. It thus becomes the pre-occupation of all concerned to ensure that the teaching job takes its rightful place and offers the desirable result for our educational system.

\section{Implication of the Study}

Based on the findings from this study, students' academic performance in Oyo state schools need to be urgently attended to. This requires prompt attention on the part of the state educational planners and policy makers to improve the academic situation of the state schools from its present state through provision of necessary equipments into our various schools and to crate conducive working environment for teachers.

\section{Conclusion and Recommendations}

For qualitative education, the education stakeholders must make adequate planning as regards ensuring the effective performance of teachers in the state through quality assurance mechanism needs to be put in place and implemented for continuous monitoring of each school's input, process and output. Though the study portrays a favourable characteristics of the average Nigerian teachers toward the success of teaching-learning process in a given classroom situation. However, this does not mean that the teachers are completely innocents of the educational problems in this nation. Despite the unfavourable working environment which teachers are subjected to through the lackadaisical attitude of Government at all levels as regards provision of funds in improving the status of our schools. The authority concern in charge of teachers monitoring should rise up to their duty as expected. Finally, the teachers' welfare should also be put into consideration since teachers are panacea for attainment of educational goals and objectives. If truly, this nation sees education as determinant of progress in all ramification then teachers should be monitored so as to perform their duties as expected and the moral aspects of life because the learners are making use of them as their role models. 


\section{References}

Adesina, B. (2001). Basic Principles of Supervision. New York: American Book .

Adufe, W. (2005). The Heart of Teaching (Chap. 1 pp. 1-5). Citadel books, Ibadan.

Aremu, A.O. (2002). Application of Psychology to Secondary School Teaching. In Ayodele S.O. (Ed), Teaching Strategies for Nigerian Secondary School (Chap. 1 pp. 3-13). Powerhouse Press and School publishers.

Blumende, R.S. (2001). Making Schools effective in Nigeria. Journal of Education Research, 5(1), 65-78.

Briggs, T. (2002). Improving Instruction through Supervision. New York : The Macmillan Company.

Ekwesili, O. (2006). Our Educational System. Paper presented at the Presidential Forum on Education. Abuja: October.

Fabunmi, M. (2002). The Use of Sociology in Teaching at the Secondary School level. In Ayodele S.O. (Ed), Teaching Strategies for Nigerian Secondary School (Chap. 1 pp. 3-13). Powerhouse Press and School Publishers.

Federal Republic of Nigeria (2006). National Policy on Education. NERDC, Abuja. Federal Ministry of Education (2005). Education Sector Analysis Report, Abuja.

Federal Republic of Nigeria (2007). National Policy on Education. NERDC, Abuja. Federal Ministry of Education (2005). Education Sector Analysis Report, Abuja.

ljaiya, NYS (1998). An investigation into the problems of teachers' management in Kwara State Secondary Schools. Studies in Educational planning and Administration, 1(2), 49-58

Kerlinger, F.N. (1979). Foundations of Behavioural Research. (2nd Ed.) New York: Holt, Rinehart and Winston.

Oyosaju, S. (2004). A Guide to School Effectiveness in Nigeria. Ibadan. Laville Publications.

Owolabi, S.O. (2007). Teacher education in sub-Saharan Africa: Policies and practices. Paper presented at the Development of Teacher Education in Africa Conference. Makarere University, Kampala, Uganda. August 4-6.

Rodgers, T.S. (2001). Language teaching methodology. Eric Digest. September, Issue paper.

Ryan, D.G. (1947). Appraising Teachers' Personnel, Journal of Experimental Education, Vol. 16, No. 1. 
